\title{
Localisation in the 2004 Presidential Election
}

Campaign in Taiwan

An Iconographic Approach

\section{Benson Wai Kwok Wong}

\section{OpenEdition}

\section{Journals}

Édition électronique

URL : http://journals.openedition.org/chinaperspectives/415

DOI : 10.4000/chinaperspectives. 415

ISSN : 1996-4617

\section{Éditeur}

Centre d'étude français sur la Chine contemporaine

Édition imprimée

Date de publication : 1 octobre 2004

ISSN : 2070-3449

\section{Référence électronique}

Benson Wai Kwok Wong, « Localisation in the 2004 Presidential Election Campaign in Taiwan », China Perspectives [En ligne], 55 | september - october 2004, mis en ligne le 24 juin 2008, consulté le 28 octobre 2019. URL : http://journals.openedition.org/chinaperspectives/415; DOI : 10.4000/

chinaperspectives.415

Ce document a été généré automatiquement le 28 octobre 2019

(c) All rights reserved 


\title{
Localisation in the 2004 Presidential Election Campaign in Taiwan
}

An Iconographic Approach

\author{
Benson Wai Kwok Wong
}

1 This article uses symbols, colours, gestures or slogans photographed during the electoral campaign in Taipei to present an iconographic review of the 2004 presidential election in Taiwan. Symbols, as Lowell Dittmer has argued, "exist independently of human beings and may transmit meanings from person to person despite vast distances of space and time"1. Symbols can actively promote political beliefs, ideas and/ or meanings in a covert or overt manner, and can be an important means by which to understand political action and achieve political and cultural ends ${ }^{2}$. The functions of symbols include: delivering a message in a direct and forceful way, leaving an immediate and deep impression on the target group, encouraging the internalising of perceptions, and influencing values, behaviour and decisions.

2 Inspired by Hans J. Morgenthau's assertion of the relationship between propaganda and diplomacy, we have, to a certain extent, applied this assertion to analyse the electoral propaganda in the 2004 presidential election in Taiwan ${ }^{3}$. Propaganda is important in helping to promote and reinforce beliefs by challenging ideas and currently held beliefs. It can even help to change beliefs. Propaganda creates, recreates, uses and can cement convictions, values and preferences, in the aim of persuading people to share a common goal and interests. Propaganda also creates icons that serve as a political identity for voters, as Murray Edelman argues, "[men] create political symbols and they sustain and develop them or wrap them"4. The same assertion is shared by Lowell Dittmer, saying that "human communities do set forth comprehensible and relatively consistent rules of usage to facilitate speed and fidelity of communication" ${ }^{5}$. Icons, symbols and slogans provide the raw data for analysis and interpretation-an approach useful in the study of both individual and collective behaviour.

Buttressing local identity

3 The ways in which the contesting parties promoted local identity throughout the election, were useful in helping us to examine how they perceive and construct an 
image of Taiwan. The Democratic Progressive Party (DPP) and the Taiwan Solidarity Union (TSU) tend to present the island with a positive image. According to them, a number of political miracles have occurred here, most notably that it is the first Chinese society where full democracy can be practiced. It is also the first chinese society where the institutionalisation of power transfer through the election of the national leader by universal suffrage can be achieved. It has also achieved a peaceful end to authoritarian KMT rule and a beginning to localised rule by the DPP.

1 Taiwan in lights - ceiling display at DPP election headquarters

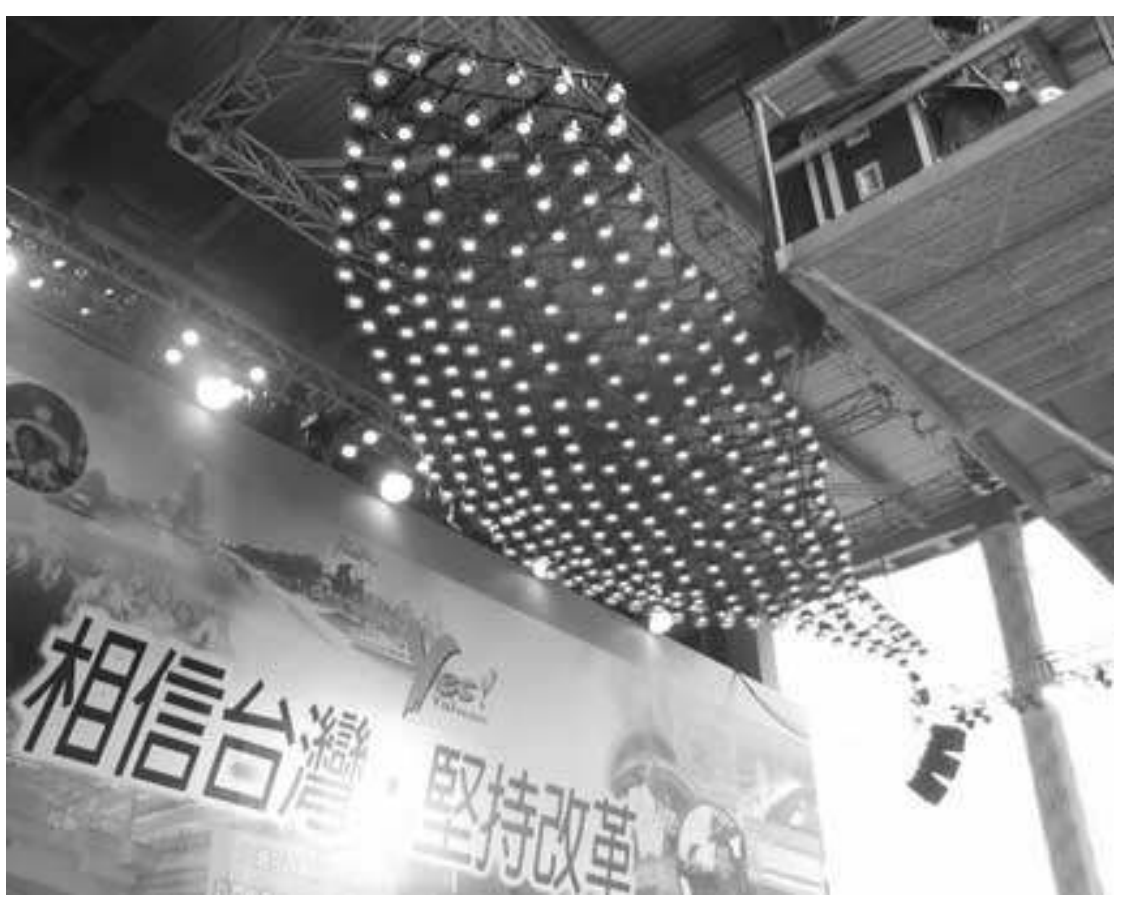

4 Such positive images are seen in the first two photos-the first shows a number of eyecatching green lights in the shape of the island of Taiwan and placed on the ceiling of the DPP campaign headquarters. Taiwan is at the top, and everyone has to "look up to" Taiwan. Additionally, since green is the colour of the DPP, the green lights imply that Taiwan is under the protection of the DPP. 
2 With "Yes, Taiwan" on his cheek and "Yes, Taiwan" flag in hand, a young Taiwanese campaigns for List No. 1 - Chen Shui-bian and Annette Lu

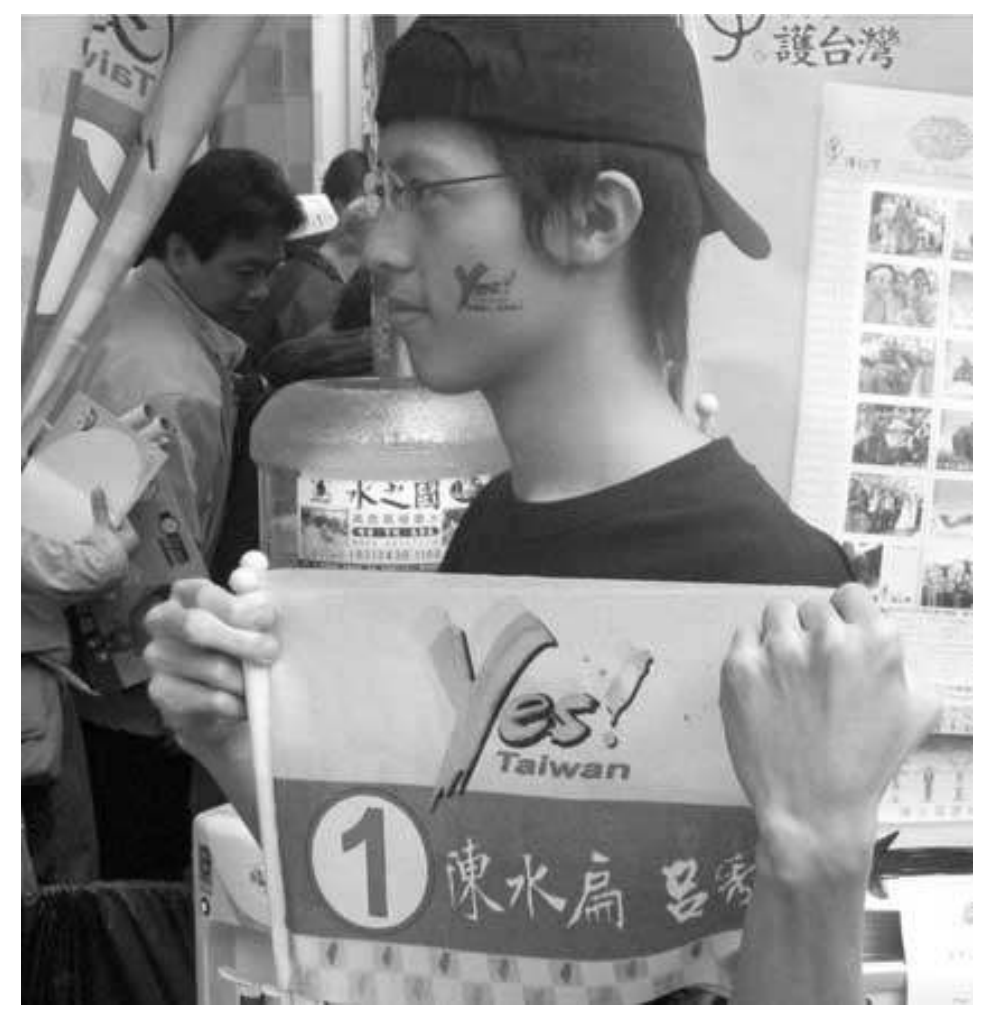

2 shows the slogan "Yes! Taiwan" tattooed on the face of a youngster and also on the flag in his hand. The exclamation mark after the "Yes" is in the shape of Taiwan. The Taiwanese have a strong determination to fulfil their aspirations: besides defending their island, the intend to follow through the reforms, as shown by the DPP slogan (Photo 4): "Believing in Taiwan and persisting with reform" (xiangxin Taiwan, jianchi gaige).

6 The promotion of Chen Shui-bian as a local Taiwanese and a capable leader shows that Taiwan, even if isolated, can stay standing in the international arena, and face internal and external challenges, including the threat of the PRC. Chen's emphasis on "localisation" or "Taiwanisation" does not mean however that the KMT-PFP-NP alliance is unaware of its importance.

7 The KMT employed the term "New Taiwanese" (xin Taiwanren) to create a new image that was a departure from the traditional image. James Soong first used the concept when he ran for governor of Taiwan in 1995, and then Ma Ying-jeou used it when contesting the 1998 Taipei City mayoral race. However, the term could be interpreted in a number of ways. It lacked a clear message and depth of understanding, and criticism claimed that it could be understood as "the division of Taiwanese old and new. James Soong promotes the independence of Taiwan in a covert manner" 6 . To portray a KMT rooted in Taiwan, its election campaign would not heavily emphasise unification as this would imply that Taiwan would be merged with mainland China, and the possibility of the island losing its autonomy. Of course, the KMT is striving to reestablish its image as a local political force by accepting that most of the forums were conducted in a bilingual format-Taiwanese (taiyu) and Mandarin-so as to soften the image of "Waishengren" (people from mainland China). 
3 KMT Chairman Lien Chan (centre), wife Lien Fang Yu, and party secretary-general Lin Feng-cheng, kiss the ground at a election rally in Taipei, 13 March 2004

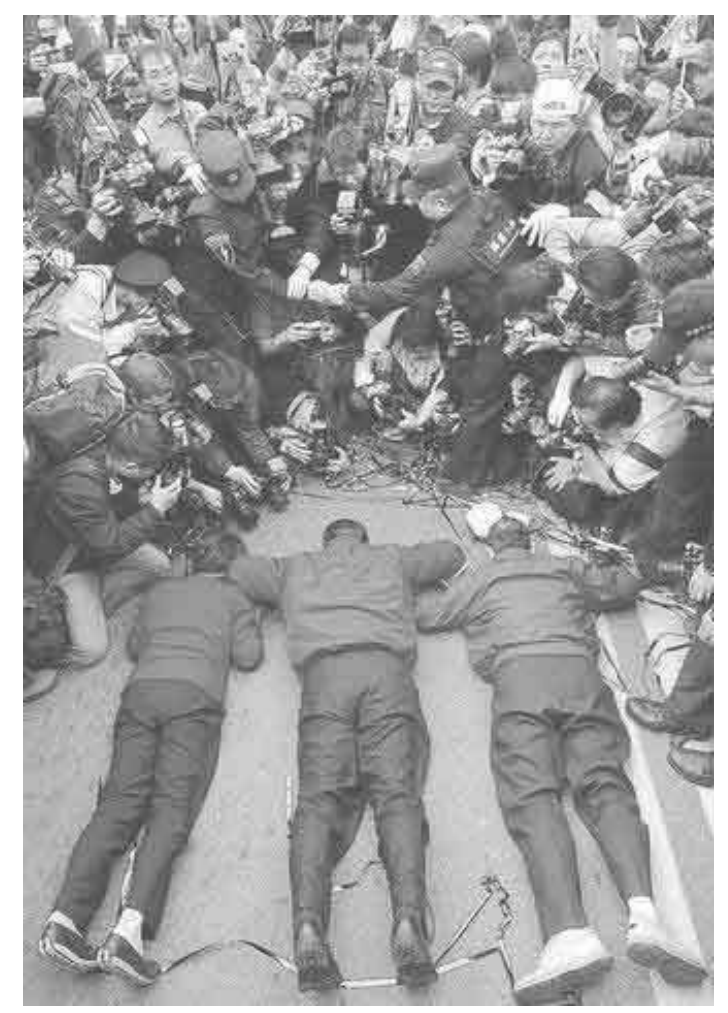

Source: Taipei Times, 14 March 2004

During the campaign rallies for the 2004 presidential election, the KMT-PFP political alliance attempted to go beyond the concept of the "New Taiwanese", and to a certain extent followed a similar strategy adopted by the DPP to promote "Taiwan's identity", stressing their love for Taiwan and recognising that they are a part of Taiwan. Photo 3 shows Lien Chan, chairman of the KMT, with his wife and the secretary-general of the Nationalist party, kissing the land to show their love for the island. The KMT is determined to reconstruct itself and its image: no longer an alien political party that came from mainland China in 1949, but a localised political party rooted in Taiwan and working for Taiwanese. Taiwanisation became a key element of the campaigning during this presidential election in order to win the hearts and minds of voters.

Taiwan's capacity to face political challenges

The Taiwanese are proud that their island is the first Chinese society to enjoy full democracy. Chen Shui-bian, in his first inaugural speech, given on May 20th, emphasised Taiwan's political achievement of becoming a model of democracy not only for Chinese society, but for the wider Asian society also. He declared that: "On the eve of the twenty-first century, the people of Taiwan have completed a historic alternation of political parties in power. This is not the first of its kind in the history of the Republic of China, but also an epochal landmark for Chinese communities around the world. Taiwan has not only set the new model for the Asian experience of democracy, but also added an inspiring example to the third wave of democracy the world over. [...] Today, it is as if we are standing before a fresh new gate in history. In the process of democratisation, the Taiwanese people have created a brand-new key to our shared 
destiny. The new century's gates of hope are soon to open. We are humble but not submissive. We are full of self-confidence but not the slightest bit of self-satisfaction" 7

10 A similar message was conveyed in his inaugural speech in 2004, emphasising the successful democratic experience of Taiwan under his governance over the past four years: "What we have come together to witness are the progressive steps of Taiwan's democracy, as well as a story, written jointly by the 23 million people of Taiwan-one that is extraordinary and truly remarkable. [...] In the final year of the twentieth century, Taiwan crossed a historic doorsill, completing an unprecedented transfer of power between political parties, and ushering in a new era in our nation's democratic development. [....] In the eyes of Chinese societies and other emerging democratic states, Taiwan's democracy embodies not merely a democratic experimentation; it signifies an exemplary success. The standard of democracy achieved by Western nations is the result of experience through the test of time. In comparison, Taiwan's newfound democracy, after weathering rough waters, has burgeoned into an even more precious accomplishment"'.

4 Slogans at DPP headquarters. "Believe in Taiwan", "Push ahead with reforms"

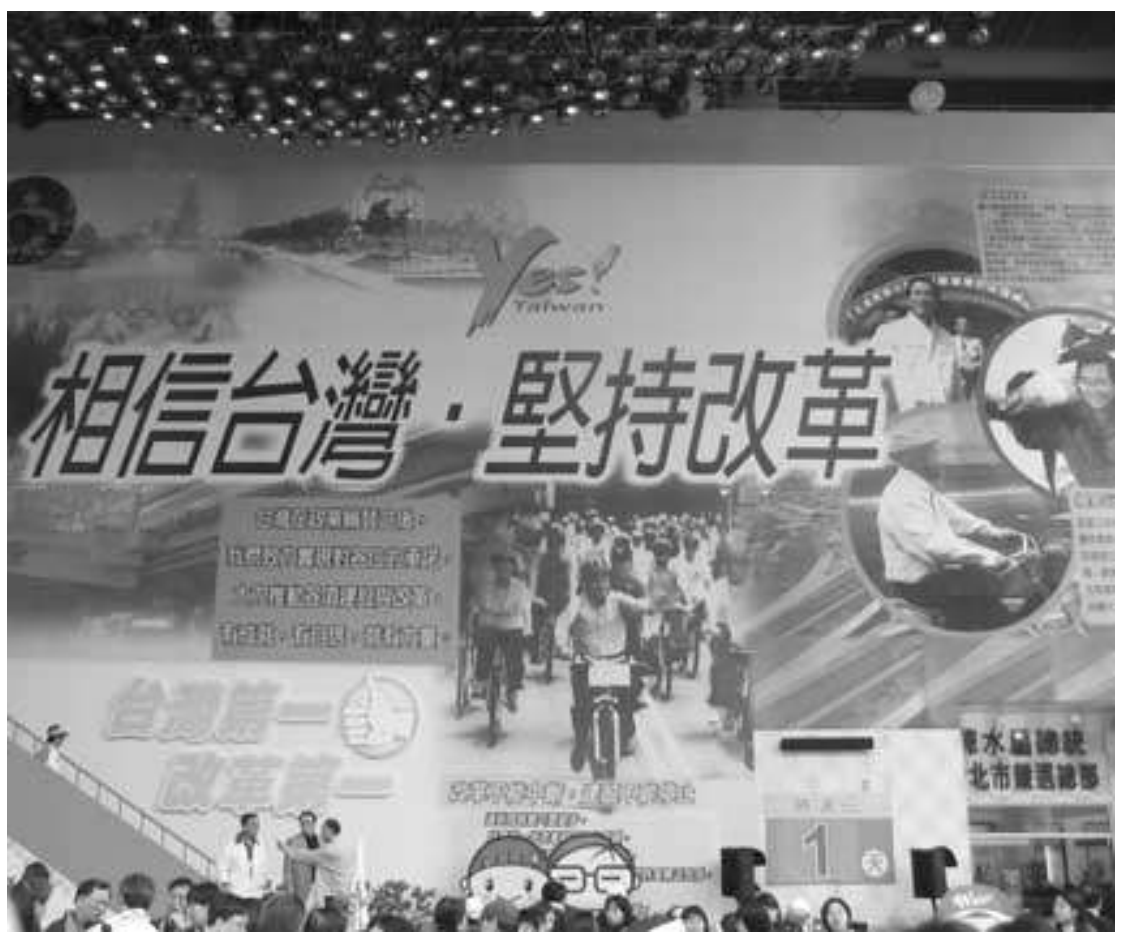

Chen reiterated several political challenges faced by the Taiwanese in the process of democratisation, notably the transfer of power from an old ruling regime to a new party, and the setting up of a new mode of democracy for a Chinese society. Photos 4 and 5 illustrate the determination of Taiwanese political parties to win through the political challenges facing them. In photo 4, the DPP claims: "Believing in Taiwan and persisting with reform", "With achievement and self-confidence, we have the power", and "Taiwan No. 1 and Reform No. 1". On photo 5, the figure "100" can be interpreted in three ways: 100 is full marks in the Taiwanese education system, so Taiwan can achieve the best possible result in the democratic transition; " 1 " in the 100 is an appeal to the voters to cast a vote for the ticket "1", the ticket of Chen Shui-bian and Annette $\mathrm{Lu}$; the design inside the two "0"s is the stamp that voters mark on the ballot: it is 
inspired by and adapted from the symbol for peace, meaning that voters should also participate in the referendum to uphold peace in the cross-Strait region'. Thus, according to the DPP's election campaign political challenges such as undergoing a smooth transfer of power, upholding the reforms, and holding a referendum for the maintaining of peace and order in Taiwan, could be won with the support of the people.

5 DPP election poster. "Referendum, First Priority" and "Taiwan 100" [out of 100]

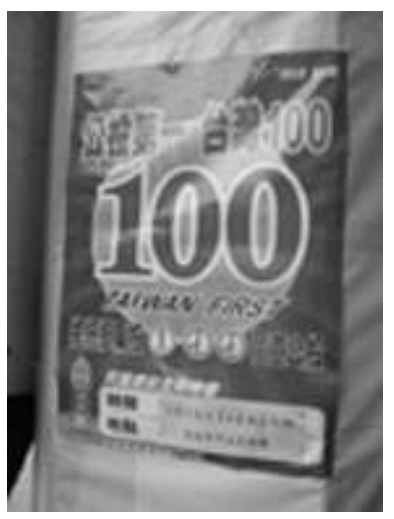

The KMT-PFP alliance had a different view of Taiwan's present landscape, advocating that Taiwan's crisis is due to Chen's inefficient administration and his confrontational approach to the opposition. The alliance's message was clear: that the only way to save Taiwan from further decline and decay was to vote for them to effect a second round of power transfer from the DPP to the KMT-PFP alliance. The major theme of the election campaign run by the KMT was to "strive for the economy and strive for peace, save Taiwan", as can be seen in photo 6, taken inside the campaign headquarters of the KMT. In short, Taiwan must revitalise its economy by reconstructing and maintaining harmonious and co-operative relations with mainland China.

6 At KMT election headquarters. List No. 2, "Fight for the economy, Give our all for Peace, Save Taiwan"

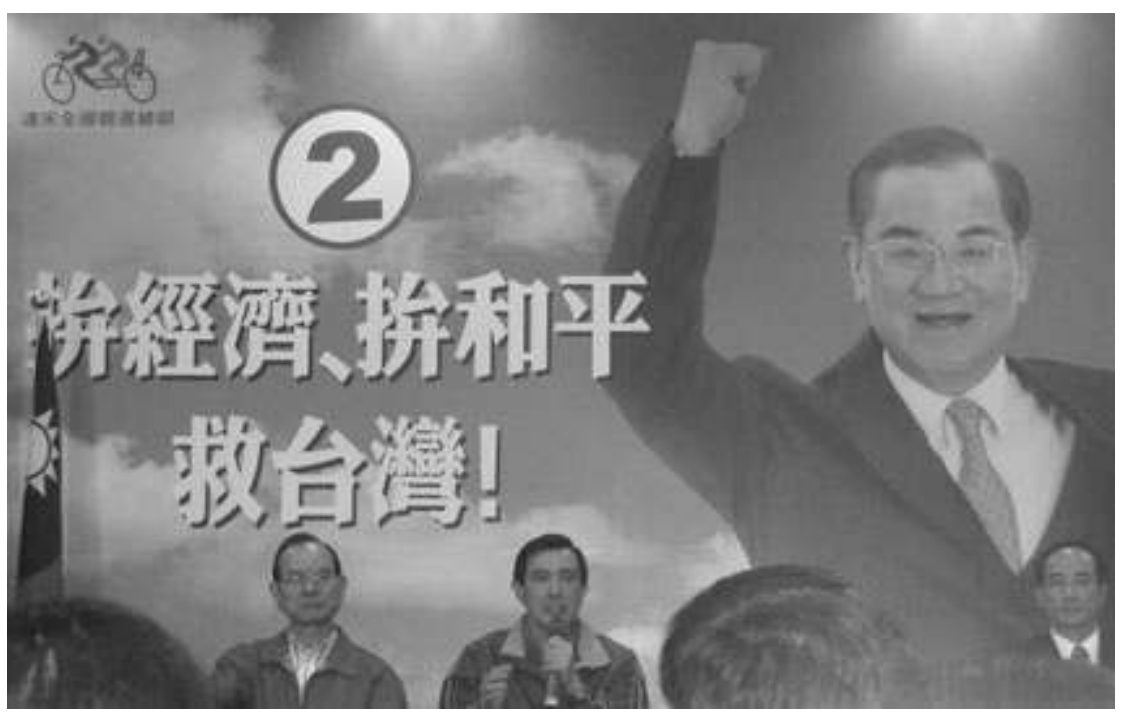

Both groups took Taiwan's identity as the major theme of their campaign rallies, yet with a very different view of the local situation. While the DPP adopted a positive stand, saying that Taiwan could overcome any difficulties and insisting on the unique 
character of the island, which it would bring to the political situation, the KMT-PFP alliance held that Taiwan was facing economic crisis, political disturbance, and tense relations with the PRC, suggesting it was time for the Taiwanese to effect a further transfer of power.

Chen Shui-bian as the "symbol of Taiwan"

In his promotion of the DPP, Chen Shui-bian has succeeded in constructing an image of himself as the "symbol of Taiwan", importantly in this that he was born in Taiwan, not on the mainland, that he struggled for democracy and freedoms against the authoritarian regime of the KMT in the late 1980s, that he has adopted a tough stance towards the PRC to portray himself as "defender" of the island and its people and systems, and that he has encouraged the proliferation of the indigenous culture ${ }^{10}$.

7

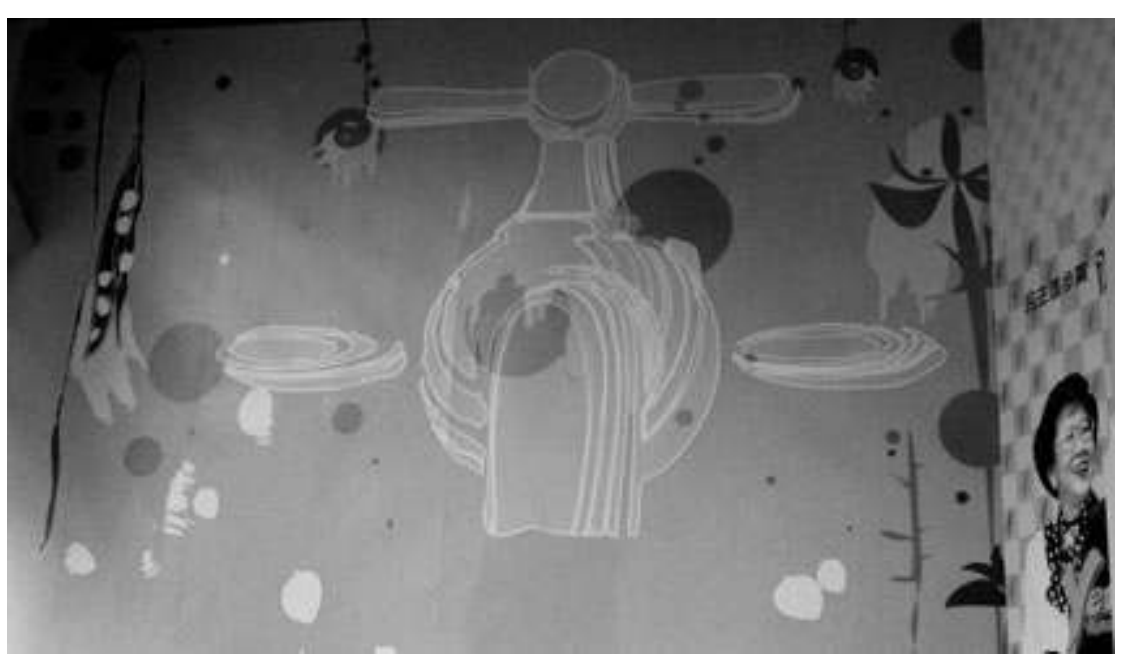

8 Taps

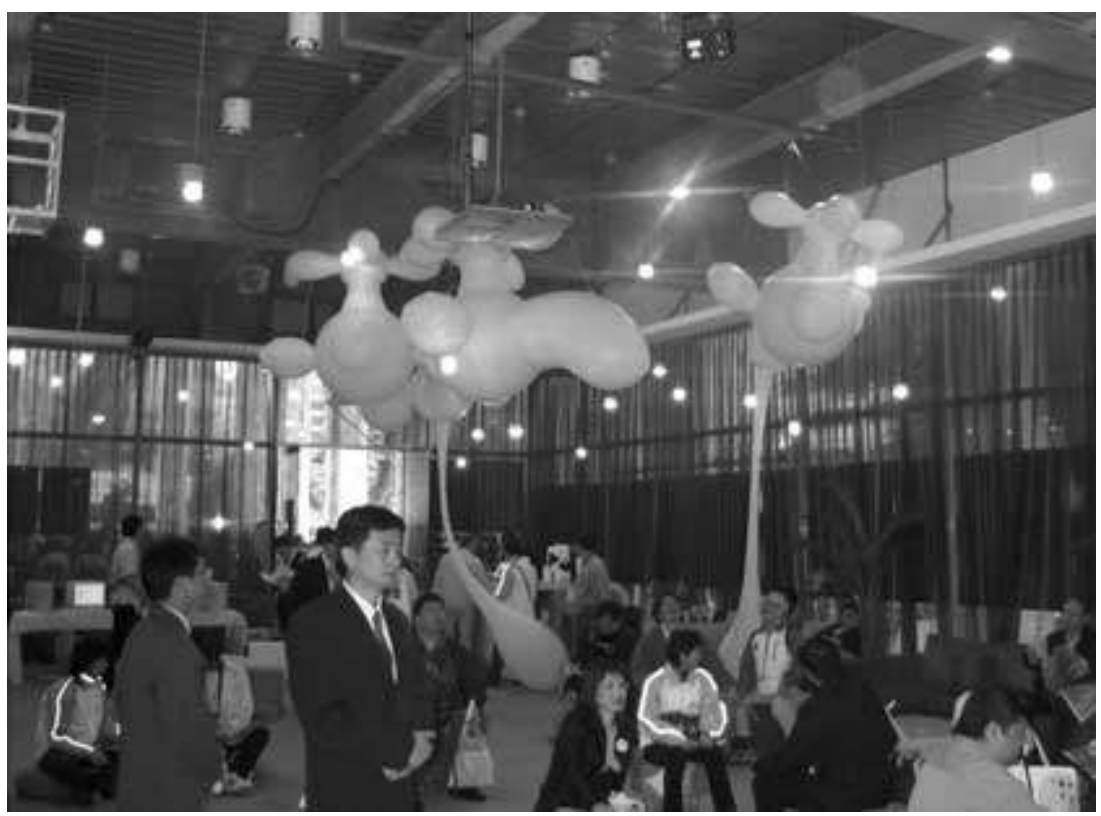

He developed these images of himself during the campaign rallies, first as a reformer leading Taiwan down the road of reforms (photo 4 , he is on a bicycle leading the other 
cyclists). Water also symbolises Chen since shui, the first character of his given name, means "water". The running water pouring from the taps in photos 7 and 8 signifies a continuation of the reforms in his second term and that prosperity will be sustained. Finally, unlikely most political leaders who portray themselves as charismatic and charming, Chen adopts a more casual approach portraying himself as an energetic and friendly role model in order to attract younger voters. Photos 9 and 10 depict Chen and Lu in a comical way, making them accessible to the young generation. Lien Chan has also adopted this strategy (Photo 11).

9 The A-Bian family

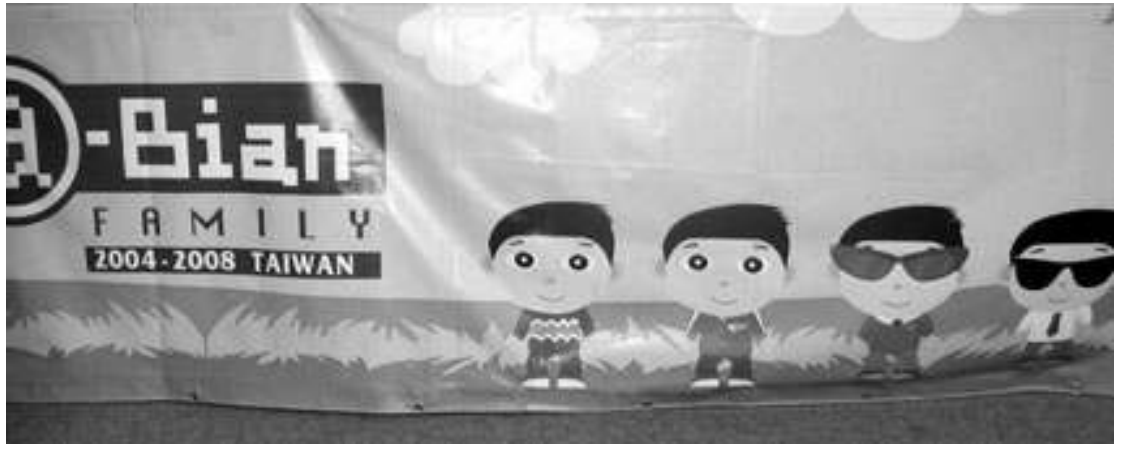

10 Chen Shui-bian and Annette Lu

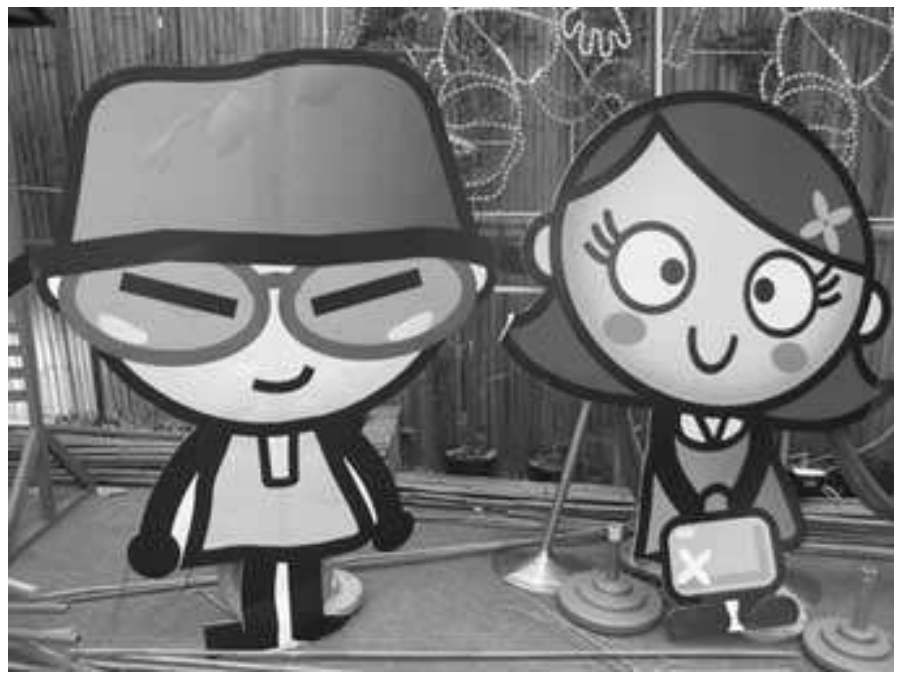




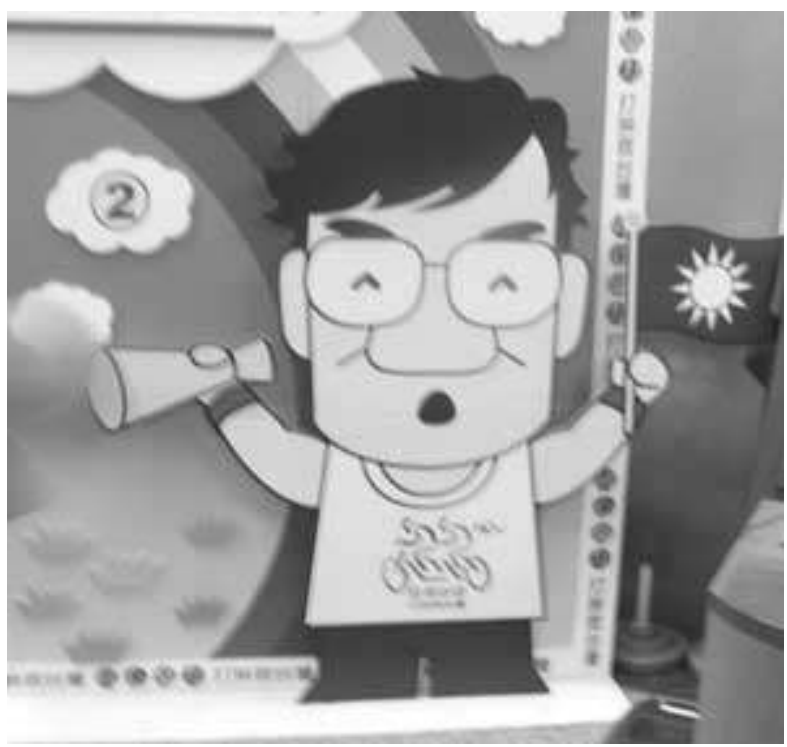

Chen calculated that the youth vote accounted for a large proportion of the voting population. He therefore adopted a more casual approach to win their support. The creation of the "A-bian" family (Photo 9) was part of this strategy as was its design as, while it also operated like, a fan club. This was intended to mobilise supporters and voluntary workers (zhigong) in the campaign rallies.

Lien Chan and James Soong seemed to prefer to retain their charismatic image, focusing on public speeches to appeal directly to their audiences.

The hostility towards the PRC

This assertion will be examined in two ways: the rejection of the PRC's "one China" principle and "One Country Two Systems" as the proposed future path for Taiwan; the abhorrence of and the resistance towards the PRC's negative remarks and military threats.

Following the same strategy adopted in the 2000 presidential election, the KMT did not strongly advocate a "one China" policy. Both candidates said the Republic of China (ROC) was an independent sovereign state ${ }^{11}$. Lien Chan strongly asserted that "Macau was a colony, so was Hong Kong, but we are not. The Republic of China has been a sovereign state since its founding in 1912. We would become citizens of a colony according to the way they treat us. Isn't that ridiculous?"12. According to a public opinion survey jointly conducted by the Mainland Affairs Council (MAC) and the Elections Study Centre of National Chengchi University between April 23rd and 25th $2004,80.8 \%$ of the respondents disapproved of the adoption of the "one country two systems" formula and of accepting Taiwan as a local government of the PRC, stating that the Taiwanese people "overwhelmingly regard themselves as a sovereign nation on an equal footing with China"13.

Considering these circumstances, the Taipei government could have solid justification for rejecting the national unification proposal, notably the "one country two systems" approach $^{14}$. This observation, in turn, is supported by the defeat of the same political experiment currently practiced in Hong Kong (in particular by the rejection of the weak and docile Chief Executive and his ruling clique as defenders of the political interests of the Hong Kong people, the presence of pro-government social and 
economic elites that serve as mouthpieces for central government in Peking, and the PRC's intervention in the administration of Special Administrative Region, etc.). This situation has led to a determination among the Taiwanese that Taiwan will not and shall not be a second Hong Kong. Chen Shui-bian has claimed that "many of our citizens have told me that we have made enough concessions and shown our sincerity to the fullest, yet we have received little positive response from the Chinese mainland. They told me not to make any more concessions"15.

21 The Peking authorities still adopt a tough policy towards the Taiwanese, and threats of military action if "Taiwan independence" is pursued. During the 2000 presidential election, the People's Liberation Army Daily asserted "Taiwan independence means war", and accused the United States of lending "hegemonic support" to Taiwan's independence so that the island could be used as a base to contain China ${ }^{16}$. Zhu Rongji, the former Prime Minister of the People's Republic said that if Taiwan voters elected the wrong candidate, they might not be given another chance ${ }^{17}$. Worse still, the PRC government profoundly devalues political developments towards independence in Taiwan, asserting that: "Judging from the extreme views on 'Taiwan independence' advocated by Chen Shui-bian, 'Taiwan independence' is the key factor that would lead to worsening cross-Strait relations and instability across the Taiwan Strait. Chen uses 'democracy' to promote 'independence'. He tries to make false promises to the Taiwanese people, distorts public opinion, and uses 'independence' to undermine the interests of the Taiwanese. His one-party and one-person rule cannot be fulfilled in this regard"18.

22 An identical position was taken in the 2004 presidential election: "We understand and respect the Taiwan compatriots' desire for developing democracy, but we firmly oppose the Taiwan authorities' pursuit of 'Taiwan independence' and any splittist activities under the cloak of democracy" ${ }^{19}$. After Chen made his inaugural speech on May 20th 2004, the Peking authorities insisted on such tough remarks against Chen, saying that: "Chen Shui-bian, who attempted to cheat the public in his 'inauguration speech' on May 20th, still sticks to his 'Taiwan independence' stance. As such the cross-Strait situation remains severe" ${ }^{20}$. 
12 A DPP election poster. "The National Assembly shows the way", "Referendum - 20 March", "Greens set for landslide victory", "The Master of the Nation is impressive", "Blues Out, with the Reds", "Missiles", "28 February hand in hand"

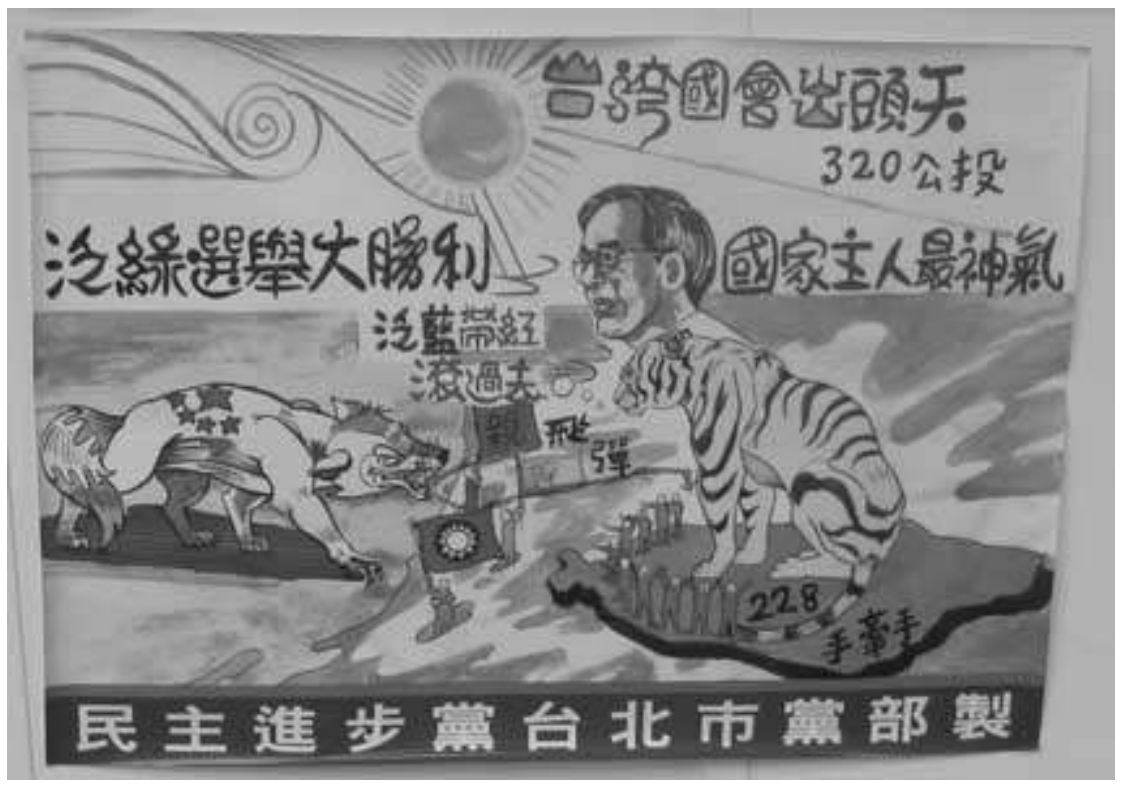

As a result, this deep misunderstanding and insistent and inflexible approach on the part of the PRC towards Taiwan's political developments has ultimately led to a hostility among Taiwanese towards the PRC. Focusing on the DPP's election campaign, photo 12 shows a cartoon portraying the negative Taiwanese perception of the PRC. The cartoon shows an image of a Taiwanese people bravely standing up to its neighbour. Taiwan is coloured green with Chen Shui-bian depicted as a tiger proudly facing the mainland. A number of people also coloured green stand hand-in-hand facing the mainland, showing, through the use of the word "missiles" (feidan) on Taiwan's side, a united Taiwanese people undaunted by the mainland's military threats ${ }^{21}$. The PRC is portrayed as a cunning fox facing Taiwan, its jaws open, showing its intention. The KMT, the PFP and the New Party are placed between mainland China and Taiwan, thus "marginalised". The cartoon strongly implies that the PRC and KMT share a common feature, that both are aliens in the eyes of the DPP. The message is clear. In order not to allow a repetition of the agony and horror of Chiang Kai-shek's rule, the Taiwanese must do their utmost to dispel the PRC's threat ${ }^{22}$.

The KMT-PFP alliance approach towards the PRC is in stark contrast. Conciliatory in nature, it focuses instead on the view that communication between the mainland and Taiwan should be resumed for the benefit of Taiwan. Photo 13 shows Lien and Soong advocating the establishment of direct flights between the island and the mainland for the benefit of Taiwanese businessmen working in mainland China, thus expressing a willingness to maintain and strengthen economic and cultural ties.

Underlying these differing approaches are the very different perception that each group has of the PRC. While the DPP tends to maintain a defensive position in its relations with the mainland, seeing it as a threat, the KMT-PFP alliance do not overlook the importance of the role that the mainland has in stabilising Taiwan's political situation and the importance of maintaining peaceful relations with its neighbour as a great asset to the Taiwanese while still espousing Taiwan's sovereignty. 
13 KMT poster. "Daddy will be home for supper - direct flights within two years", "A-Bian can't do it - Lien and Soong promise they will"

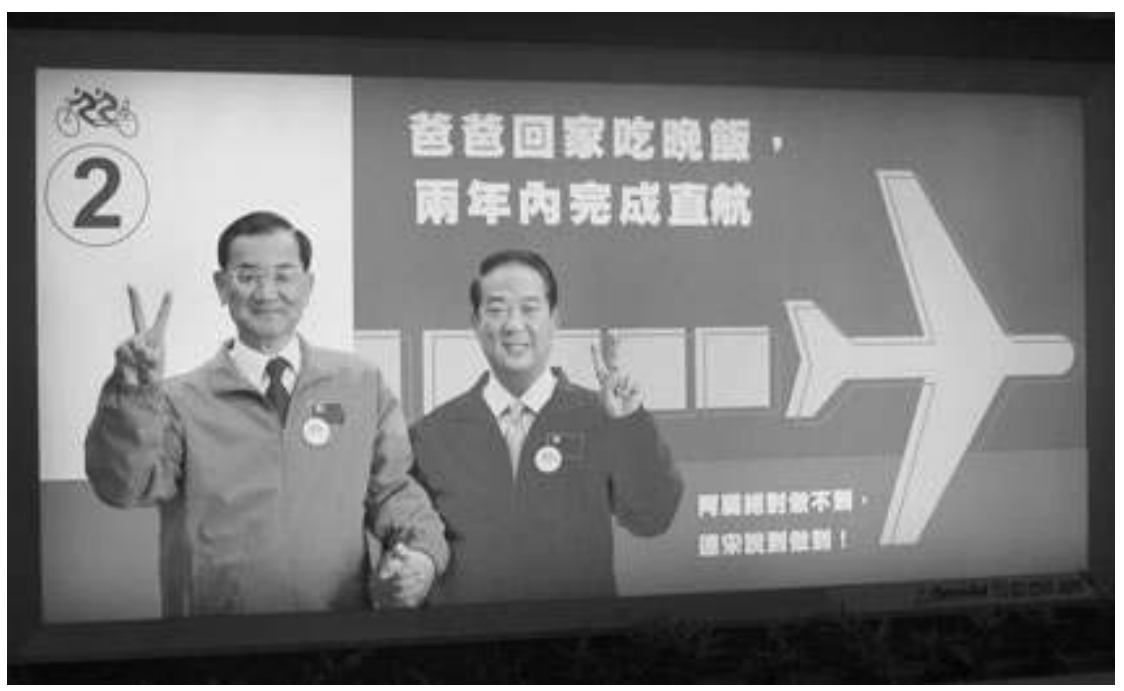

Despite the fact that the data we have chosen to use here is limited to Taipei city, the study is meaningful in showing how Taiwan identity was expressed during the presidential election. An analysis of the overt and underlying meanings of icons, symbols and slogans led us to three conclusions:

"Localisation" or "Taiwanisation" is an inevitable trend in the sense that the Taiwanese virtually regard Taiwan as a de facto nation; yet while they choose to recognise this, they also choose not to voice this formally to avoid antagonising the mainland authorities. This is reflected in the relatively low vote of $45 \%$ for a referendum.

The KMT is no longer a political party hailing from the mainland; instead it has become a local party with public recognition, especially in southern Taiwan, reflected in the use of the "Taiwanese language" during rallies to construct an image of a friendly, understanding and approachable party, important as southern Taiwan is not a KMT power base. This trend, to a certain extent, shows that campaign strategies are inspired by the popularity of the DPP, and thus that localisation is the only effective way of gaining public recognition and support.

Finally, the trend towards localisation poses the PRC authorities with a dilemma. If Peking adopts a hard-line policy towards the Taipei government, this unintentionally stimulates Taiwanisation since most Taiwanese regard the government in Peking as an unfriendly and ambitious neighbour eager to annex Taiwan for complete unification. On the other hand, if Peking recognises the growth and development of Taiwanisation, it may imply "toleration" on the part of the PRC authorities of Taiwan independence. This would be an illusion. 


\section{NOTES}

1. Lowell Dittmer, "Political Culture and Political Symbolism: Towards a Theoretical Synthesis", World Politics, Vol. 29, No. 4, July 1977, p. 557.

2. Mabel Berezin. "Political and Culture: A Less Fissured Terrain", Annual Review of Sociology, Vol. 23, 1997, pp. 364-373. As a study of the intensive adoption of religious symbols in the political setting, see Ezra Kopelowitz and Matthew Diamond, "Religion That Strengthens Democracy: An Analysis of Religious Political Strategies in Israel", Theory and Society, Vol. 27, No. 5, October 1998, pp. 671-708.

3. See Hans J. Morgenthau, Politics Among Nations: The Struggle for Power and Peace, New York: Alfred A. Knopf, 1972.

4. Murray Edelman, The Symbolic Uses of Politics, Urbana and Chicago, University of Illinois Press, 1967, p. 1. See also Gary D. Rawnsley, "Selling Taiwan: Diplomacy and Propaganda", Issues \& Studies, Vol. 36, No. 3, May/June 2000, pp. 1-25.

5. Lowell Dittmer, op. cit., p. 557.

6. "Jiekai Song Chuyu xinTaiwanren minzuzhuyi de hulugai" (Taking the cover off James Soong's Nationalism for the New Taiwanese), Times Voice Journal (http:// www.timesvoice.com.hk), April 1st 2001 <http://www.timesvoice.com.hk/02_editorial/ 0401/Ed_158.htm> (downloaded on April 20th 2004).

7. Chen Shui-bian, "Taiwan Stands Up: Toward the Dawn of a Rising Era", Republic of China Tenth-Term President Chen Shui-bian's Inauguration Address, May 20th 2000, quoted from American Asian Review, Vol. XVIII, No. 2, Summer 2000, p. 142.

8. Chen Shui-bian: "Paving the Way for A Sustainable Taiwan", Republic of China Eleventh-Term President Chen Shui-bian's Inauguration Address, May 20th 2004 http://www.taipei.org/president/chen2004520.html (downloaded on August 30th 2004).

9. "The 11th Presidential, Vice-presidential and Nationwide Referendum", The Central Election Commission, The Government of the Republic of China (downloaded on April 19th 2004). The two issues were: (1) The People of Taiwan demand that the Taiwan Strait issue be resolved through peaceful means. Should mainland China refuse to withdraw the missiles it has targeted at Taiwan and to openly renounce the use of force against us, would you agree that the Government should acquire more advanced antimissile weapons to strengthen Taiwan's self-defence capabilities? and (2) Would you agree that our Government should engage in negotiations with mainland China for the establishment of a "peace and stability" framework for cross-Strait interactions in order to build consensus and for the welfare of the people on both sides?

10. See Chen Shui-bian, The Son of Taiwan. Taipei, Morning Star Group Publishing Company Limited, 1999.

11. See Sheng Lijun, "Chen Shui-bian and Cross-Strait Relations". As for the KMT, its official website states "the ROC has sovereignty over Taiwan, both de facto and de jure. Nothing can alter this. In conclusion, we want to emphasise that defending the ROC is the best way to express patriotism and love for Taiwan. In contrast, denying the existence of the ROC is a dangerous route to pursue and will harm Taiwan. For a significant period of time, Taiwan's pro-independence parties have maliciously attacked the ROC and claimed it has hindered Taiwan's development. However, history shows that the ROC has contributed substantially to Taiwan over the past fifty years or 
so. The destinies of the ROC and Taiwan are entwined and cannot be separated". Zhongguo Guomindang chuanqiu zizuanwang (The World Wide Web Site of the Chinese Kuomintang) <http://www.kmt.org.tw/Aboutus/English/Aboutus-12-5.html> (downloaded on May 6th 2004). See also "Taiwan President implies his Island is a Sovereign State", New York Times, July 13th 1999.

12. "Taiwan is a sovereign state, not Hong Kong and Macau" <http://taiwantt.org.tw/ fortaiwan/fortaiwan6/new_page_6.htm> (downloaded on April 20th 2004)

13. "Poll shows insistence on ROC sovereignty", Taiwan Journal, May 8th-14th, 2004 $<$ http://publish.gio.gov.tw/FCJ/current/04051461.html> (downloaded on May 14th 2004).

14. The "one country two systems" idea was first suggested not in connection with Hong Kong, but in connection with Taiwan. In the first half of the 1980s, the PRC government promised that it would not "liberate" Taiwan, and would deal with Taiwan according to the "actual circumstances" on the island. On December 4th 1982, the new Chinese Constitution was adopted at the Fifth National People's Congress. Article 31 in Chapter One, General Principles, stipulates that "the state may establish special administrative regions where necessary. The systems to be instituted in special administrative regions shall be prescribed by law enacted by the National People's Congress in the light of specific conditions". Despite the fact that the "one country two systems" concept was not specifically mentioned, the idea of such a concept was stressed to the effect that the PRC would allow the presence of a "capitalist" system in some territory of mainland China after unification. Compiled by Li Kwok-sing (translated by Mark Lok), A Glossary of Political Terms of The People's Republic of China. Hong Kong: The Chinese University Press, 1995, p. 524-525; Zheng Zange, Lianan Guanxi Bianqian Shi (History of the Changing Cross-Strait Relations), Taipei, Zhouzhi Wenhua Zhubanshi, 1996, pp. 244-245.

15. "ROC President Chen Shui-bian's Press Conference, July 31st 2000", American Asian Review, Vol. XVIII, No. 4, Winter 2000, p. 176.

16. James A. Robinson and Deborah A. Brown, "Implications of Taiwan's Vote for Change”, American Asian Review, Vol. XVIII, No. 2, Summer 2000, p. 155.

17. Ibid.

18. "Comments on Chen Shui-bian's speeches on 'Taiwan's Independence' in 2003", Renmin ribao (Overseas Edition), January 5th 2004, p. 5.

19. "NPC spokesperson slams Taiwan 'referendum", extracted from <news.xinhuanet.com/english/2004_03/04/content_1344987.htm>, accessed on 31 August 2004.

20. "Official: Cross-Strait situation still severe", extracted from <news.xinhuanet.com/ English/2004_06/09/content_1516857.htm>, accessed on 31 August 2004.

21. The people holding hands is also an allusion to the meeting organised on February 28th by the DPP and the TSU to commemorate the massacres of the February 28th 1947 (228).

22. A red line is drawn to connect both the PFP and the New Party to Taiwan. The KMT is excluded. 


\section{RÉSUMÉS}

The 2004 presidential election campaign in Taiwan brought head to head the political alliance of the Kuomintang (KMT), the People's First Party (PFP) and the New Party (NP) on one side, and of the Democracy Progressive Party (DPP) and the Taiwan Solidarity Union (TSU) on the other. Adopting an iconographic approach, this article looks at four aspects of "Taiwanisation": a stronger Taiwan identity, the island's ability to face political challenges arising from democratisation and political unrest, Chen Shui-bian as the symbol of Taiwan, and the Taiwanese hostility towards and distrust of mainland China.

INDEX

Thèmes : politique 